\title{
PENGARUH COVID 19 BAGI PENDIDIKAN ANAK USIA DINI DI KAITKAN DENGAN HADIST MENUNTUT ILMU DI TK ISLAM NAJMAH RUGAYAH DARUS MEDAN HELVETIA
}

\author{
Abdul Muthalib \\ abdulmuthalib.thalib@yahoo.co.id \\ Sekolah Tinggi Agama Islam Sumatera Medan \\ Juliana \\ azanjuliana@gmail.com \\ Sekolah Tinggi Agama Islam Sumatera Medan \\ Dina Wijayanti \\ dinawijayanti01@gmail.com \\ Sekolah Tinggi Agama Islam Sumatera Medan \\ Puput syahputri \\ rudi67762@gmail.com \\ Sekolah Tinggi Agama Islam Sumatera Medan
}

\begin{abstract}
This research discusses the obstruction of activites in the world of early childhood education due to the covid 19 pandemic. The study aims to determine the extent of the Islamic kindergarten education institution Najmah Rugayah Darus, and it is associated with the tradition of the prophet Muhammad about the obligation to study. Data collection was carried out by means of research observation, interviewing school principals, teachers and seeing data on the number of students in school notebooks (documents) of the Islamic kindergarten education institution Najmah Rugayah Darus, the results of the research and interviews are described,and analyzed. The Islamic kindergarten education institution Najmah Rugayah Darus changes the teaching and learning proces, learning model even although due to covid 19the number of students has decreased. Hopefully the policies taken by the Islamic kindergarten education institution Najmah Rugayah Darus can be emulated by other early childhood education institutions.
\end{abstract}

Keywords:.Covid-19, early childhood education

\begin{abstract}
Abstrak: Penelitian ini membahas tentang terhambatnya kegiatan di pendidikan anak usia dini akibat pandemi covid 19. Penelitian ini bertujuan untuk mengetahui sejauh mana pengaruhnya di lembaga pendidikan Tk Islam Najmah Rugayah Darus dan dikaitkan dengan hadis-hadis Nabi Muhammad SAW tentang kewajiban menuntut ilmu. Pengumpulan data dilakukan dengan cara observasi riset mewawancarai kepala sekolah, guru dan melihat data jumlah anak didik di buku catatan (dokumen) sekolah Tk Islam Najmah Rugayah Darus, hasil riset dan wawancara dideskrifsikan dan dianalisis. Hasil analisis diketahui bahwa Tk Islam Najmah Rugayah Darus merubah tempat proses belajar mengajar, model pembelajar, walaupun akibat covid 19 ini jumlah peserta didik berkurang. Semoga kebijakan yang diambil oleh Tk Islam Najmah Rugayah Darus bisa dicontoh oleh lembaga pendidikan anak usia dini lainnya
\end{abstract}

Kata Kunci: Covid 19, Pendidikan Anak Usia Dini. 


\section{Pendahuluan}

Saat ini dunia dihadapkan dengan masalah yang rumit yaitu perang melawan covid 19 (corona virus diseas), semua negara terkena dampak dari covid 19, Banyak negara yang berusaha menemukan obat covid 19, namun sampai saat ini belum di temukan, semua kegiatan manusia yang biasa dilakukan tehalang karena dampak covid 19.

Covid 19 mudah tertular ke orang lain hanya dari droplet ( suatu cairan atau cipratan air liur yang di keluarkan seseorang dari hidung ataupun dari mulut saat bersin, batuk, maupun berbicara ), orang yang terjangkit covid 19, bahkan jika droplet tersebut menempel disuatu tempat dan orang lain memegangnya masuk kemulut hingga tenggorokan akan mengakibatkan kematian. Sehingga pemerintah Indonesia terutama mentri pendidikan melarang proses belajar mengajar dengan tatap muka di sekolah-sekolah, termasuk Pendidikan Anak Usia Dini (PAUD).

Oleh karena itu kami ingin mencoba meneliti / meriset hal-hal tentang PAUD pada masa pandemic covid 19 ini. Pendidikan anak usia dini di Tk Islam Najmah Rugayah Darus adalah salah satu yang terdampak covid 19, yang beralamat jl. Kapten Muslim no 50 Medan. Banyak kegiatan PAUD yang tidak dapat di lakukan seperti biasanya, anak didik tidak dapat belajar di sekolah, karena takut terkena covid 19, Sementara itu pendidikan harus dilakukan karena pendidikan adalah awal mula atau dasar dari manusia yang berkualitas yang dapat memajukan negara. Manusia wajib menuntut ilmu dan orang yang berilmu harus mengajarkan ilmunya ke pada orang lain, berdasarkan hadis Rosullah SAW

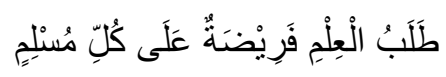

"Menuntut ilmu itu wajib atas setiap muslim" (HR. Ibnu Majab).'

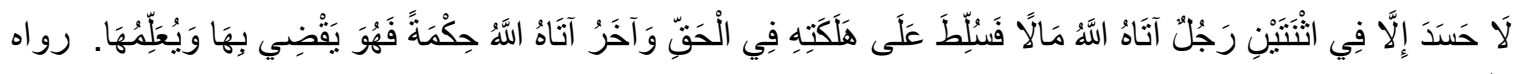

"tidak boleh iri hati kecuali terhadap dua perkara yaitu terhadap seseorang yang dikaruniakan oleh Allah harta kekayaan tetapi dia memanfaatkanya untuk urusan kebenaran. Juga seseorang yang diberikan ilmu pengetahuan oleh Allah SWT lalu ia memanfaatkannya serta mengajarkannya kepada orang lain."(HR. Bukhari \& muslim). ${ }^{2}$

Berdasarkan hadis di atas setiap orang muslim wajib menuntut ilmu maka tidak ada suatu apapun yang dapat menghalangi manusia untuk menuntut ilmu, karena menuntut ilmu adalah sunah Nabi Muhammad SAW bukan hanya menuntut ilmu yang wajib dilakukan manusia, tetapi orang yang berilmu akan lebih bermanfaat jika ilmunya diajarkan ke orang lain, ilmu akan bermanfaat jika diamalkan sendiri, keluarga maupun mengajarkannya kepada orang lain kemudian orang lain tersebut mengamalkannya. Berdasarkan konteks di atas maka kami ingin meneliti bagaimana pengaruh covid 19 terhadap pendidikan anak usia dini di Tk Islam Najmah Rugayah Darus di Medan Helvetia.

Tujuan penelitian ini dibuat untuk mengetahui sejauh mana pengaruh covid 19 terhadap Pendidikan Anak Usia Dini di TK Islam Najmah Rugayah Darus Medan Helvetia dikaitkan

\footnotetext{
${ }^{1}$ Yazid bin Abdul Qadir Jawas, Ritual sunah setahun,cet. 3, (Bogor: Media Tarbiyah, 2016), h 53.

${ }^{2}$ Zainuddin Ali, Pendidikan Agama Islam, cet 4, (Jakarta: PT. Bumi Aksara, 2012), h 45.
} 
dengan hadis-hadis menuntut ilmu, untuk mengetahui data-data jumlah anak didik di Tk Islam Najmah Rugayah Darus sebelum dan sesudah covid 19, untuk mengetahui kebijakan apa yang diambil sekolah Tk Islam Najmah Rugayah Darus agar proses belajar mengajar tetap berlangsung. Penelitian ini di buat berdasarkan observasi, wawancara terstruktur, dan berdasarkan temuantemuan atau dokumen yang ada di sekolah Tk Islam Najmah Rugayah Darus, yang kemudian dideskripsikan dan semoga yang artikel ini bermanfaat bagi yang membacanya. Penelitian ini juga dibuat untuk memenuhi tugas kelompok KKN Daring STAI Sumatera sebagai salah satu syarat kelulusan menjadi S1 PIAUD.

\section{Kajian teori}

\section{Pengertian pendidikan anak usia dini}

Undang-Undang Nomor 20 Tahun 2003 tentang pendidikan Nasional Pasal 1 angka 14 Pendidikan anak usia dini adalah suatu upaya pembinaan yang ditujukan kepada anak sejak lahir sampai 6 tahun melalaui pemberian rangsangan membantu pertumbuhan dan perkembangan jasmani dan rohani agar anak memiliki kesiapan memasuki pendidikan selanjutnya. ${ }^{3}$ Usia $0-6$ tahun adalah masa perkembangan dan pertumbuhan yang sangat menentukan bagi anak di masa depannya atau disebut juga masa keemasan (the golden age) sekaligus periode yang sangat kritis yang menentukan tahap pertumbuhan dan perkembangan anak selanjutnya. ${ }^{4}$

Ini menjadi dasar pendidikan anak usia dini di Tk Islam Najmah Rugayah Darus Medan Helvetia tetap menjalankan proses belajar mengajar walapun sampai saat ini negara Indonesia masih mengalami pandemi covi 19. Tk Islam Najmah Rugayah Darus adalah salah satu pendidikan anak usia dini yang tetap melakukan proses belajar mengajar tetapi dengan menerapkan protokol kesehatan covid 19 yaitu dengan belajar luring atau luar jaringan (bome visit), guru mengajar ke rumah anak didik, menggunakan masker, cuci tangan sebelum dan sesudah kegiatan, menjaga jarak atau social distancing.

Inilah yang menjadi dasar penelitian ini di buat, untuk mengetahui sejauh mana pengaruh covid 19 terhadap pendidikan anak usia dini di Tk Islam Najmah Rugayah Darus, Bagaimanakah cara sekolah Tk Islam Najamah Rugayah Darus mengambil kebijakan agar proses belajar mengajar tetap terlaksana dengan baik di masa pandemi covid 19 ini dan untuk mengetahui jumlah anak didik sebelum dan sesudah covid 19.

Pendidikan anak usia dini adalah suatu pembinaan tumbuh kembang anak sejak usia lahir hingga enam tahun secara menyeluruh yang mencangkup aspek fisik dan nonfisik dengan memberikan rangsangan bagi perkembangan rohani dan jasmani (moral dan spiritual), motorik akal pikir, emosional dan sosial yang tepat agar anak dapat tumbuh dan berkembang secara optimal. ${ }^{5}$

\footnotetext{
${ }^{3}$ Mukhtar latif, Zukhairina, Rita Zubaidah, Muhammad Afandi, Orientasi Baru Pendidikan Anak Usia Dini Teori dan Aplikasi, (Jakarta: Kencana Prenadamedia Group, 2014), h. 4.

${ }^{4}$ Suyadi, Maulidya ulfah, Konsep dasar Paud, cet. 3, (Bandung: PT. Remaja Rosda karya), h. 2.

${ }^{5}$ Mansur, Pendidikan anak usia dini dalam islam, cet. 5, (Yogyakarta: Pustaka Pelajar, 2014), h. 88.
} 


\section{Tujuan Pendidikan Anak Usia Dini}

Tujuan pendidikan anak usia dini memberikan stimulasi atau rangsangan untuk pertumbuhan dan perkembangan jasmani dan rohani menjadi lebih baik, manusia beriman dan bertakwa kepada Tuhan Yang Maha Esa, berakhlak mulia, besosial antara manusia dengan baik, berilmu, pintar, kritis sebelum melanjutkan ke pendidikan selanjutnya yaitu sekolah dasar.

Pendidikan sangatlah perlu bagi anak agar anak mampu tumbuh dan berkembang dengan baik, rohani maupun jasmaninya. Oleh sebab itu Sebagai orang tua harus memilih pendidikan yang terbaik untuk anaknya sejak dini, mampu memilih tempat pendidikan yang terbaik yaitu pendidikan yang berkualitas, terutama pendidikan yang berbau agama, karena pendidikan terdasar untuk anak adalah pendidikan keimanannya. Sebagaimana firman Allah SWTT.

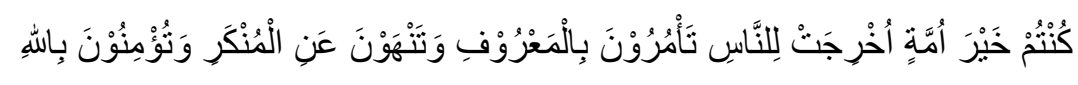

"Kamu adalab umat yang terbaik yang dilabirkan untuk manuasia, menyurub kepada yang ma'ruf dan mencegah dari yang munkar, dan beriman kepada Allab"(QS. Ali Imran ayat 110).

Untuk mencapai Kualitas umat terbaik, selain menyuruh kepada kebaikan, melarang kejahatan maka umat Islam harus konsisiten dalam keimanan tauhid. ${ }^{6}$ dapat disimpulkan bahwa manusia yang terbaik dihadapan Allah SWT tidak hanya manusia yang mau menegakkan kebenaran atau menyuruh kepada kebaikkan dan melarang kejahatan, tetapi harus mempunyai keimanan yang konsisten yaitu tetap beriman kepada Allah SWT. Tidak hanya menjadi umat yang baik tetapi juga mendapatkan pahala yang besar, sesuai hadis Rosul SAW.

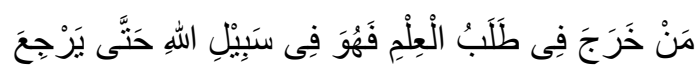

"Barang siapa yang keluar untuk mencari ilmu, maka ia termasuk di jalan Allah Sampai ia kembali." (RH.Tirmidzi).

Artinya menuntut ilmu adalah berjuang di jalan Allah SWT, pahala orang yang menuntut ilmu sama dengan pahala orang yang berjuang di jalan allah SWT. Dan jika ia meninggal saat menuntut ilmu agama maka ia mati syahid sama halnya orang yang meninggal berperang di jalan Allah SWT yaitu menegakkan kebenaran menjauhkan kejahatan yang sesuai perintah Allah SW'T.

Usia yang tepat untuk mengajarkan anak tau mendidik anak menurut ajaran agama islam yaitu sejak usia dini sejak umur usia dini Rosul SAW menyuruh agar anak dikenalkan untuk ikut serta sholat bersama keluarga, kemudian pada usia 7 tahun anak sudah boleh di suruh mengerjakan sholat dan umur 10 tahun jika tidak mengerjakan sholat maka boleh dipukul. Sesuai hadis Rosullulah SAW,

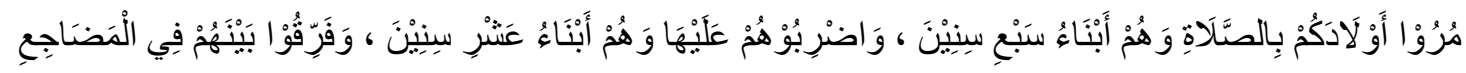

\footnotetext{
${ }^{6}$ Syafaruddin,et. al, Ilmu Pendidikan Islam Melejitkan Potensi Budaya Umat, cet. 5 (Jakarta: Hijri Pustaka Utama, 2014), h. 3.

${ }^{7}$ Mustofa Al-khin, et. al., Imam Nawawi, Syarah \& Terjemah Riyadhus Shalihin,(Jakarta : Al- I'tishom, 2012), Jilid II , h. 537.
} 
"perintabkan anak-anakmu melaksanakan sholat sedangkan mereka berusia tujub tahun dan pukullah mereka karena tinggalkan sholat sedang mereka berusia 10 tabun dan pisabkan antara mereka di tempat tidurnya"(HR. Abu Dawnd). ${ }^{8}$

Hadis diatas menjelaskan cara mendidik agama pada anak haruslah sejak dini sehingga nanti setelah dewasa ia tau apa yang di perintahkan Allah SWT dan apa yang dilarang oleh Allah SWT sebab itu sangatlah penting untuk mendidik anak sejak dini dengan nilai-nilai agama. agar anak tidak keluar dari keimanannya dan mengetahui apa yang boleh dikerjakan sesuai ajaran agama dan yang tidak boleh dikerjakan sesuai peraturan Agama. Pendidikan anak usia dini dapat membina tumbuh kembang rohani dan jasmani anak baik spritual, motorik, emosional, sosial dan memebentuk karakteristik anak menjadi baik. Tidak hanya di lembanga pendidikan yang berperan penting dalam mendidik anak keluarga adalah yang utama dalam membentuk karakteristiknya dengan baik dan benar.

Orang yang hidup bersama dalam satu tempat tinggal disebut keluarga masing-masing anggota keluarga merasakan adanya pertautan batian sehingga saling memperhatikan. ${ }^{9}$ Orang yang paling berperan dalam pendidikan anak adalah orang tua, maka sebaiknya sebagai orang tua dan keluarga harus pintar memilih pendidikan yang terbaik untuk anak, sebaiknya diberi pendidikan sejak usia dini, karena di usia dinilah anak mulai berkembang dengan baik di masa inilah disebut golden age masa keemasan anak, karena anak usia dini memiliki rasa ingin tau yang besar, suka meniru atau mencontoh orang lain maka harus ditanamkan sifat baik dan ilmu yang baik agar menjadi dasar atau karakter anak. Sebelum menuntut ilmu (belajar) hendaklah orang tua mengajarkan anaknya untuk menghormati gurunya atau mengajarakan anak untuk berakhlak atau menjaga adabnya.

Seorang penuntut ilmu harus menjaga diri dari akhlak-akhlak yang tercela. Sebab akhlak yang tercela atau yang buruk itu ibarat anjing. ${ }^{10}$ Alangkah hinanya jika di sebut anjing karena merupakan hewan yang haram jadi sangatlah penting adab sebelum ilmu, terutama yang harus di jauhi yaitu sikap sombong karena dengan kesombongan ilmu tidak bisa diraih. Maka haruslah orng tua cerdas dalam mendidik dan memilih pendidikan untuk anak.

Ada tiga jalur ruang lingkup pendidikan anak usia dini yakni formal, non- formal dan informal. ${ }^{11}$ Ruang lingkup pendidikan anak usia dini formal yaitu pendidikan ysng sudah mempunyai izin dari pemerintah contohnya Taman Kanak Kanak (TK), Raudhatul Athfal (RA) dan bentuk pendidikan lainnya yang telah berizin. Pendididkan non formal adalah pendidikan anak usia dini yang didirikan belum mempunyai izin oleh pemerintah Pendidikan informal adalah pendidikan yang dibangun atau diselenggarakan oleh keluarga dan lingkungan hanya sebatas didikan tanpa terstuktur dan tidak memerlukan izin dari pemerintah.

Tk Islam Najmah Rugayah Darus adalah termasuk pendidikan formal, salah satu pendidikan anak usia dini yang masih peduli dengan dunia pendidikan yang masih memperhatikan anak

\footnotetext{
${ }^{8}$ Abdul Majid Khon, Hadist Tarbawi Hadis- Hadis Pendidikan, cet. 2, (Jakarta:Prenadamedia, 2014), h. 263.

${ }^{9}$ Moh. Shocib, Pola Asuh Orang Tua Dalam Membantu Anak Mengembangkan Disiplin Diri, (Jakarta: Rineka Cipta, 2017), h. 17.

${ }^{10}$ Imam Az-Zarnuji, Ta 'limul Muta'allim Pentingnya Adab Sebelum Ilmu, cet. 4, (Solo: Aqwam, 2019), h. 75.

${ }^{11}$ Suyadi, Teori Pembelajaran Anak Usia Dini Dalam Kajian Neurosains, (Bandung: PT. Remaja Rosdakarya, 2014), h. 24.
} 
didiknya. Dengan tetap belajar mengajar walaupun dengan metode belajar di rumah peserta didik (bome visit) artinya mereka tidak membiarkan kebodohan, sesuai hadist nabi Muhammad SAW.

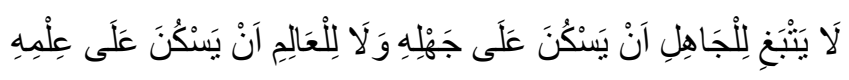

"Tidak pantas bagi orang bodoh mendiamkan kebodohannya, juga tidak pantas orang yang berilmu itu mendiamkan ilmunya" (HR. Ath-Tharbrani, Ibnu Sunni, dan Abu Nu'aim). ${ }^{12}$

Berdasarkan hadis diatas Rosul SAW melarang manusia untuk mendiamkan kebodohon, ilmu yang dimiliki haruslah disampaikan kepada orang lain, walaupun dalam keadaan pandemi covid 19.

\section{Metode penelitian}

Penelitian ini adalah penelitian campuran (mixed menthods), percampuran antara data kuantitatif dan data kualitatif untuk memperoleh analisis masalah penelitian, dengan mengumpulkan kedua data tersebut, kemudian menggabungkannya menjadi satu data informasi hasil keseluruhan dari suatu masalah. Penelitian ini dibuat berdasarkan observasi, wawancara, dan pengumpulan data dokumenter untuk mengetahui sejauh mana pengaruh covid terhadap pendidikan anak usia dini di Tk Islam Najmah Rugayah Darus.

\section{Hasil Dan Pembahasaan}

Covid 19 atau corona virus yang ditemukan akhir tahun 2019 tepatnya Desember 2019 di wuhan china yaitu penyakit menular yang disebabkan oleh virus, mudah tertular hanya melalui droplet masuk ketenggorokan bahkan jika droplet tersebut menempel disuatu benda dipegang oleh orang lain kemudian masuk ketenggorokan mengganggu pernapasan dan menyebabkan kematian. Ada beberapa gejala seperti batuk dan sesak napas ada juga yang tanpa gejala,karena mudah tertular sehingga menjadi wabah atau pendemi yang terjadi di dunia saat ini. sampai saat ini covid 19 belum ada obatnya hanya dapat dicegah. Covid 19 ini bias mati atau hilang sebelum masuk ketenggorokan dengan mencuci tangan dengan sabun.

Setiap negara juga melarang warganya untuk memasuki daerah yang terkena covid 19, termasuk Negara Indonesia.

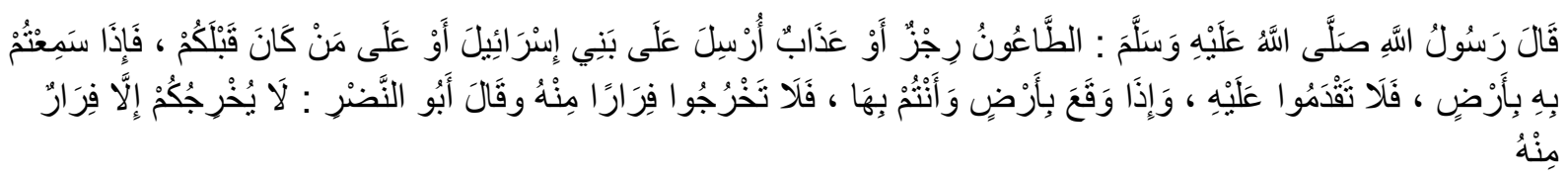

Rosulullah SAW bersabda "tha'un adalah siksaan yang dikirim kepada bani isroil dan kepada orangorang sebelum kalian. Apabila kalian telah mendengarnya di suatu bumi (daerab), maka janganlah masuk didalamnya. Dan jika ia menimpa suatu bumi yang kalian berada di dalamnya maka janganlah keluar dari bumi ini untuk. lari darinya. (shabih al-bukhari dan muslim). ${ }^{13}$

\footnotetext{
12 Syamsul Rizal Hamid, 1500 Hadis \& Sunah Pilihan, (Jakarta: Kaysa Media, 2017), h. 407.

${ }^{13}$ Ibnu Qayyim Al-Jauziyah, Zadul Ma'ad Panduan Lengkap Meraih Kebahagian Dunia Akhirat, (Jakarta: pustaka al-kautsar 2008), jilid 4, h. 38.
}

Muthalib.Juliana, Wijayanti, Syahputri - pengaruh covid 19 bagi pendidikan anak usia dini 
Berdasarkan hadis Rosulullah SAW diatas Rosul melarang orang yang terkena wabah untuk keluar dari daerahnya dan orang-orang yang tidak terkena wabah tidak boleh memasuki daerah yang terkena wabah, maka yang terkena covid 19 harus menjaga diri agar tidak menularkan dan yang tidak terjangkit covid 19. Harus menerapkan protokol kesehatan yang telah ditetapkan pemerintah mengenai pandemi covid 19 ini yaitu, jaga jarak minimal 1 meter, menggunakan masker, rajin cuci tangan dengan sabun, jangan berpergian jika tidak penting, lebih baik di rumah. Dunia saat ini berusaha berbagai cara menemukan obat covid 19 tetapi belum menemukannya, manusia hanya berusaha, hanya Allah SWT yang mampu menghilangkan covid 19 di muka bumi ini yakinlah kepada Allah karena Allah Swt Maha Kuasa dan Maha Mengetahui.

Hampir semua kegiatan yang biasa dilakukan terhalang karena pandemi covid 19. Masih tingginya angka kasus orang disebabkan covid 19 di Dunia dan di Indonesia. Melihat Perbandingan covid 19 bulan September 2020 dan bulan Oktober 2020 yang dilihat dari Koran Waspada Medan

\begin{tabular}{|l|r|r|r|r|r|r|}
\hline Keterangan & \multicolumn{3}{|c|}{ September 2020 } & \multicolumn{3}{c|}{ Oktober 2020 } \\
\cline { 2 - 7 } & Kasus & Sembuh & Meninggal & Kasus & Sembuh & Meninggal \\
\hline Dunia & 33.356 .013 & 24.665 .184 & 1.003 .150 & 35.204 .131 & 26.184 .579 & 1.039 .056 \\
\hline Indonesia & 278.722 & 206.870 & 10.473 & 303.498 & 228.453 & 11.151 \\
\hline $\begin{array}{l}\text { Sumatera } \\
\text { utara }\end{array}$ & 10.038 & 6.443 & 420 & 10.599 & 7.436 & 438 \\
& & & & & & \\
\hline
\end{tabular}

Melihat Perbandingan covid 19 bulan September 2020 dan bulan Oktober 2020 di Indonesia

\begin{tabular}{|l|l|c|c|c|c|c|}
\hline \multirow{2}{*}{ INDONESIA } & \multicolumn{3}{|c|}{ September 2020 } & \multicolumn{3}{c|}{ Oktober 2020 } \\
\cline { 2 - 7 } & Kasus & Sembuh & Meninggal & Kasus & Sembuh & Meninggal \\
\cline { 2 - 7 } & 278.722 & 206.870 & 10.473 & 303.498 & 228.453 & 11.151 \\
\hline
\end{tabular}




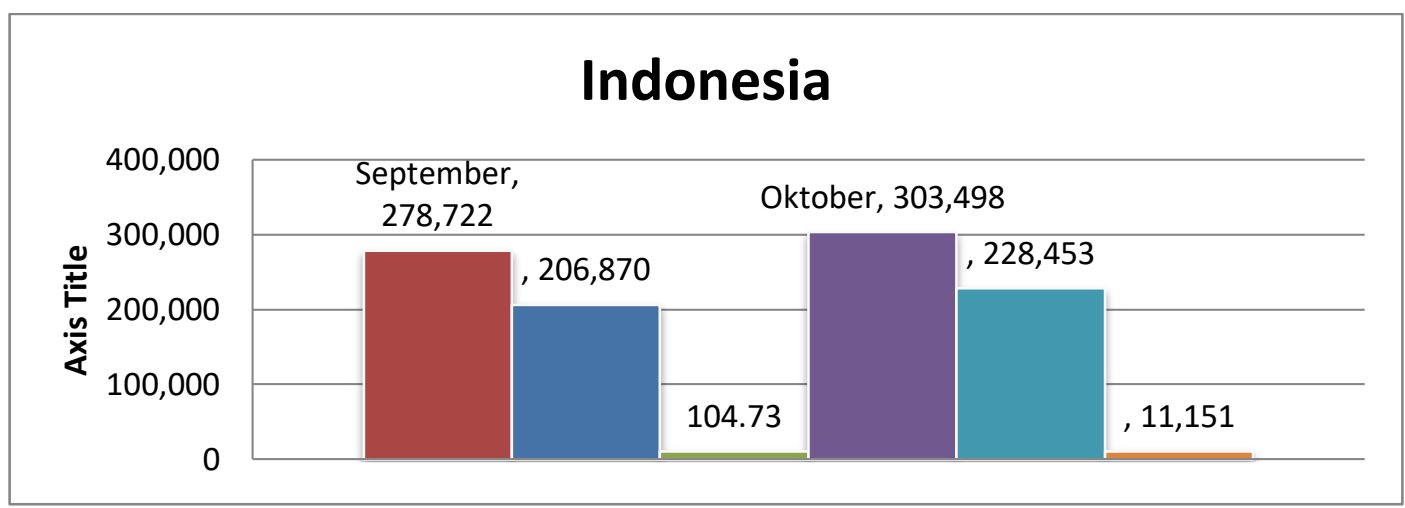

Penyebaran covid 19 di Indonesia terus mengalami peningkatan, belum terlihat melandai seperti yang di harapkan, bahkan telah menembus angka 300 ribu kasus positif. ${ }^{14}$

Dari hasil temuan data di atas dapat disimpulkan, kasus dan angka kematian disebabkan oleh covid 19 di Indonesia masih tinggi, pemerintah masih melarang kegiatan proses belajar mengajar di sekolah. Dari pendidikan anak usia dini sampai perguruan tinggi dilarang belajar tatap muka di sekolah. pendidikan anak usia dini yang terkena dampak covid 19. Tk Islam Najmah Rugayah Darus Medan Helvetia walaupun proses belajar mengajar di sekolah dilarang tetapi Tk Islam Najmah Rugayah Darus tetap melakukan proses belajar mengajar home visit (guru yang mengunjungi anak didik).

Hasil analisis deskriptif didapat melalaui observasi, wawancara dan mendapatkan data yang ada di sekolah Tk Islam Najmah Rugayah Darus Medan hevetia. lembaga pendidikan Tk Islam Najmah Rugayah Darus didirikan tahun 1996 pendirinya Dr. Najmah dan kepala sekolah saat ini Sri Hariati spd Aud, sarana dan prasarana TK Islam Najmah Rugayah Darus di lihat dari fisik bangunannya memiliki 3 ruang kelas, 2 kamar mandi peserta didik, 1 kamar mandi guru, 1 ruangan bermain 1 ruangan serbaguna, 1 ruang kepala sekolah.

Salah satu dari sarana dan prasarana itu TK Islam Najmah Rugayah Darus memiliki banyak permainan melatih motorik anak seperti jungkat jungkit, ayunan, prosotan, bola dunia. Kemudian Tk Islam Najamah Rugayah Darus mempunyai 6 orang guru:

\begin{tabular}{|l|l|l|}
\hline NO & \multicolumn{1}{|c|}{ NAMA GURU } & \multicolumn{1}{c|}{ USIA } \\
\hline 1. & Mardiani. Spd & 39 Tahun \\
\hline 2. & Lismainur. Se & 39 Tahun \\
\hline 3. & Lidya wuri. Spd & 40 Tahun \\
\hline 4. & Chairunnisa Nst. Spd & 36 Tahun \\
\hline 5. & Yusnani Sari. Spd & 48 Tahun \\
\hline 6. & Puput Syahputri & 29 Tahun \\
\hline
\end{tabular}

Berdasarkan wawancara yang lakukan kepada kepala sekolah dan guru-guru TK Islam Najmah Rugayah Darus serta hasil riset ternyata sangat besar pengaruh covid 19 ini terhadap pendidikan anak usia dini, pada awal covid 19 menyebar di Indonesia pemerintah meliburkan semua sekolah yaitu pada bulan Maret, Tk Islam Najmah Rugayah Darus mengikuti anjuran pemerintah 
meliburkan peserta didik, kemudian kepala sekolah mengadakan rapat bersama dewan guru bagaiman melanjutkan proses belajar mengajar selanjutnya, yaitu dengan menggunakan metode daring, siswa melakukan pembelajaran melalaui Whats App, kemudian saat mewisuda anak didik hanya foto wisuda saja, tanpa ada acara atau kegiatan hiburan apapun. Tahun ajaran baru, Pendidikan Tk Islam Najmah Rugayah Darus terpaksa mengambil kebijakan dengan tetap melakukan proses belajar mengajar, dengan mendatangi rumah anak murid ( home visit), proses belajar mengajar tetap dilakukan seperti biasa hanya saja, tempat belajar saja yang pindah sehingga peserta didik tetap tatap muka saat proses belajar mengajar, karena saat pembelajaran daring kurang efektip untuk anak usia dini dimana karena guru tidak dapat melihat perkembangan anak langsung.

Berikut ini hasil analisis penelitian pengaruh covid 19 di Tk Islam Najmah Rugayah Darus sebelum dan sesudah covid 19.

\begin{tabular}{|c|c|c|}
\hline No & $\begin{array}{c}\text { Proses belajar mengajar } \\
\text { sebelum covid } 19\end{array}$ & $\begin{array}{c}\text { Proses belajar mengajar setelah } \\
\text { covid } 19\end{array}$ \\
\hline 1. & Belajar mengajar di sekolah. & $\begin{array}{l}\text { Belajar mengajar berpindah-pindah } \\
\text { bergantian di rumah anak didik. }\end{array}$ \\
\hline 2. & $\begin{array}{l}\text { Belajar mengajar tanpa masker dan } \\
\text { tanpa menjaga jarak. }\end{array}$ & $\begin{array}{l}\text { Belajar mengajar menggunakan masker dan } \\
\text { menjaga jarak. }\end{array}$ \\
\hline 3. & $\begin{array}{l}\text { Setiap } 3 \text { bulan sekali atau berdasarkan } \\
\text { tema anak berkunjung ketempat tertentu } \\
\text { yang sesuai dengan tema untuk praktek } \\
\text { langsung. }\end{array}$ & $\begin{array}{l}\text { Tidak adanya kunjungan ketempat tertentu } \\
\text { untuk praktet langsung berdasarkan tema. }\end{array}$ \\
\hline 4. & $\begin{array}{l}\text { Guru melakukan proses pembelajaran } \\
\text { menggunakan alat edukatif besar mau } \\
\text { pun kecil yang ada di lsekolah untuk } \\
\text { melatih motorik anak. }\end{array}$ & $\begin{array}{l}\text { Guru melakukan proses pembelajaran hanya } \\
\text { membawa alat permainan edukatif untuk } \\
\text { melatib motorik anak yang kecil saja tanpa } \\
\text { ada permainan seperti ayunan jungkat- } \\
\text { jungkit karena belajar di rumab anak didik. }\end{array}$ \\
\hline 5 & $\begin{array}{l}\text { Jumlah kelas ada } 3 \text { yaitu TK } A \text {, Tk B } \\
\text { dan playgrop }\end{array}$ & $\begin{array}{l}\text { Jumlah kelas berkurang menjadi } 2 \text { kelas } \\
\text { yaitu TK } A \text { dan TK B karena tidake adanya } \\
\text { peserta didik yang daftar di playgrop }\end{array}$ \\
\hline
\end{tabular}

Tidak hanya proses belajar mengajar yang berubah tetapi jumlah murid yang daftar di Tk Islam Najmah Rugayah Darus juga berkurang bahkan playgrub untuk tahun ini 2020/2021 diatidakan karena tidak adanya yang mendaftar playgrub. Berikut hasil penelitian berdasarkan temuan data di buku besar Tk Islam Najmah Rugayah Darus mengenai penurunan peserta didik sebelum dan sesudah covid 19. 
Jumlah anak didik di tingkat TK A sebelum dan sesudah covid 19 di Tk Islam Najamh Rugayah Darus.

\begin{tabular}{|l|c|c|c|}
\hline \multirow{2}{*}{ Jumlah anak didik } & \multicolumn{3}{|c|}{ Tahun Ajaran pendidikan } \\
\cline { 2 - 4 } & $2018 / 2019$ & $2019 / 2020$ & $2020 / 2021$ \\
\hline Jumlah Laki- laki & 13 & 9 & 3 \\
\hline Jumlah perempuan & 12 & 11 & 1 \\
\hline $\begin{array}{l}\text { Jumlah seluruh anak } \\
\text { didik }\end{array}$ & 25 & 20 & 4 \\
\hline
\end{tabular}

Jumlah anak didik di tingkat TK B Sebelum dan sesudah Covid 19 di Tk Islam Najam Rugayah Darus.

\begin{tabular}{|l|c|c|c|}
\hline \multirow{2}{*}{ Jumlah anak didik } & \multicolumn{3}{|c|}{ Tahun Ajaran pendidikan } \\
\cline { 2 - 4 } & $2018 / 2019$ & $2019 / 2020$ & $2020 / 2021$ \\
\hline Jumlah Laki- laki & 15 & 19 & 11 \\
\hline Jumlah perempuan & 3 & 10 & 12 \\
\hline $\begin{array}{l}\text { Jumlah seluruh anak } \\
\text { didik }\end{array}$ & 18 & 29 & 23 \\
\hline
\end{tabular}

Jumlah anak didik tingkat Playgrub Sebelum dan sesudah covid 19 di Tk Islam Najmah Rugayah Darus.

\begin{tabular}{|l|c|c|c|}
\hline \multirow{2}{*}{ Jumlah anak didik } & \multicolumn{3}{|c|}{ Tahun Ajaran pendidikan } \\
\cline { 2 - 4 } \multicolumn{1}{c|}{} & $2018 / 2019$ & $2019 / 2020$ & $2020 / 2021$ \\
\hline Jumlah Laki- laki & 5 & 2 & 0 \\
\hline Jumlah perempuan & 7 & 2 & 0 \\
\hline Jumlah seluruh anak didik & 12 & 4 & 0 \\
\hline
\end{tabular}

Dengan melihat hasil temuan data diatas berdasarkan buku besar (dokumen sekolah) $\mathrm{Tk}$ Islam Najmah Rugayah Darus peserta didik sesudah pandemi covid 19 mengalami penurunan, baik di kelas TK A, TK B, dan Paygrub, dari ketiga kelas, kelas play grub di masa pandemi ini tidak ada anak didik yang mendaftar di TK Islam Najmah Rugayah Darus. 


\section{Kesimpulan}

Covid 19 sangat mempengaruhi dunia pendidikan, karena mengganggu proses belajar mengajar, Tk Islam Najmah Rugayah Darus adalah salah satu pendidikan anak usia dini yang terkena dampak covid 19, lembaga pendidikan ini tetap melakukan proses belajar mengajar karena pendidikan sangat penting bagi manusia. Bahkan Nabi Muhammad SAW bersabda menuntut ilmu wajib bagi setiap muslim. Sebaiknya dimulai saat anak usia dini masa karena masa golden age anak ( masa keemasan ) harus diberi pendidikan terutama pendidikan tentang keimanan atau ketauhidan. Walaupun dalam keadaan memerangi covid 19 yang banyak menyebabkan kematian, sebagai orng tua, pendidik bahkan pemerintah tidak boleh memebiarkan anak untuk tidak belajar. Walaupun sekolah ditutup atau proses belajar mengajar tidak diperbolehkan di sekolah pasti ada jalan keluar lainnya untuk belajar, dan sesungguhnya kematian seseorang Allah SWT yang menentukan sesuai hadis Rosulullah SAW "sesungguhnya Allah telah menulis taqdir semua makhluk lima puluh ribu tahun sebelum menciptakan langit dan bumi." Jadi jangan takut pada covid 19, kematian sudah ditentukan Allah SWT kita hanya harus menjaga atau menghindari covid 19. contohnya TK Islan Najmah Rugayah Darus adalah salah satu lembaga pendidikan yang terkena dampak covid 19 walaupun jumlah peserta didik berkurang saat pandemi ini, Tk Islam Najmah Rugayah Darus tidak putus asa dalam mendidik memberikan pelajaran kepada anak didik dengan cara home visit atau berpindah-pindah mengunjungi rumah anak didik untuk melakukan proses belajar mengajar dengan mematuhi protokol kesehatan yaitu memakai masker, cuci tangan sebelum dan sesudah kegiatan belajar mengajar bahkan sebelum dan sesudah bermain, selalu menjaga jarak, pendidikan tetap berjalan dan peserta didik dapat belajar seperti biasanya dan terhidar dari wabah covid 19.

Semoga pandemi covid 19 ini cepat berlalu normal kembali seperti biasanya. Pendidikan bisa berjalan dengan baik agar anak didik bisa belajar tatap muka kembali di sekolah anak-anak mendapatkan pendidikan yang baik agar menjadi investasi negara di masa depan karena hanya manusia yang berkualitas yang mampu menjadikan negaranya maju..

\section{Daftar Pustaka}

Khon, Abdul Majid, Hadist Tarbawi Hadis- Hadis Pendidikan, cet. 2, (Jakarta:Prenadamedia, 2014), h. 263.

Abdurrahman Al-Allamah, Fathui Majid Penjelasan Lengkap Kitab Tauhid, cet. 8. (Jakarta:Darul Haq, 2016), h. 958.

Ibnu Qayyim, Al-Jauziyah, Zadul Ma'ad Panduan Lengkap Meraih Kebahagian Dunia Akhirat, (Jakarta: pustaka al-kautsar 2008), jilid 4, h. 38.

Az-Zarnuji, Imam, Ta'limul Muta'allim Pentingnya Adab Sebelum Ilmu, cet. 4, (Solo: Aqwam, 2019), h. 75.

Mansur, Pendidikan anak usia dini dalam islam, cet. 5, (Yogyakarta: Pustaka Pelajar, 2014), h. 88.

Moh. Shocib, Pola Asuh Orang Tua Dalam Membantu Anak Mengembangkan Disiplin Diri, (Jakarta: Rineka Cipta, 2017), h. 17.

Al-khin, Mustofa, Al- Bukho Mustofa, Mistu Muhyidi, Asy Syirbaji Ali, Luthfi Muhammad Amin, Imam Nawawi, Syarah \& Terjemah Riyadhus Shalihin,( Jakarta : 2012), Jilid II , h. 537. 
Latif, Mukhtar, Zukhairina, Zubaidah Rita, Afandi Muhammad, Orientasi Baru Pendidikan Anak Usia Dini Teori dan Aplikasi, (Jakarta: Kencana Prenadamedia Group, 2014), h. 4.

Positif tembus 300 ribu", waspada,( Medan), 5 Oktober 2020, h. C1.

Suyadi, Maulidya ulfah, Konsep dasar Paud, cet. 3, (Bandung: PT. Remaja Rosda karya), h. 2.

Suyadi, Teori Pembelajaran Anak Usia Dini Dalam Kajian Neurosains, (Bandung: PT. Remaja Rosdakarya, 2014), h. 24.

Syafaruddin, Pasha Nurgaya, Maharani, Ilmu Pendidikan Islam Melejitkan Potensi Budaya Umat, cet. 5 (Jakarta: Hijri Pustaka Utama, 2014), h. 3.

Hamid, Syamsul Rizal, 1500 Hadis \& Sunah Pilihan, (Jakarta: Kaysa Media, 2017), h. 407.

Yazid bin Abdul Qadir Jawas, Ritual sunah setahun,cet. 3, (Bogor: Media Tarbiyah, 2016), h 53.

Ali, Zainuddin, Pendidikan Agama Islam, cet 4, (Jakarta: PT. Bumi Aksara, 2012), h 45.

Nuraeni, Nuraeni. “Strategi Pembelajaran Untuk Anak Usia Dini.” Prisma Sains : Jurnal Pengkajian Ilmu Dan Pembelajaran Matematika Dan IPA IKIP Mataram 2, no. 2 (2014): 143. https://doi.org/10.33394/j-ps.v2i2.1069. 